\title{
613 有限要素法によるガラスレンズのモールドプレス解析
}

\section{Numerical Analysis for Press Forming of Aspherical Glass Lens by Finite Element Medhod}

\author{
荒井 政大 (信州大) \\ 伊 藤 寛 明 (チノンテック(株)
}

\author{
○辰已 正 和 (信州大・院) \\ 松 倉 利 顕 (チノンテック(株))
}

杉本 公一 (信州大)

Masahiro ARAI, Shinshu University, 4-17-1, Wakasato, Nagano, Japan

Masakazu TATSUMI, Graduate Student, Shinshu University, 4-17-1, Wakasato, Nagano, Japan

Ko-ichi SUGIMOTO, Shinshu University, 4-17-1, Wakasato, Nagano, Japan

Hiroaki ITO, Chinontec Co., 4710, Nakasu, Suwa City, Nagano, Japan

Toshiaki MATSUKURA, Chinontec Co., 4710, Nakasu, Suwa City, Nagano, Japan

\section{1. 緒 論}

デジタルカメラや携帯電話，医療機器など，ガラス製光学 レンズの用途は年々拉大しており, 光学機器のさらなる性能 向上を目的として非球面レンズが積極的に利用されていま す.これら光学レンズ成形法として期待されているモールド プレスによる成形法は，大量生産が可能である，非球面なぞ の複雑な形状に加工が可能など，種々の利点を有している. しかしながら, ガラスの構成方程式が粘弾性特性を示す, 冷 却中に温度分布が発生するなどの様々な理由から成形条件の 最適值を事前に予測することは極めて困難であり，製造現場 においては経験的知見をもとに成形条件を決定しているのが 現状である。

そこで本研究では，ガラスレンズのモールドプレス成形に 関し，成形プロセスの最適条件を把捯することを目的として, 有限要素法による数值シミュレーショシを実施した。 今回の 報告では，非球面レンズ成形用金型を用いてガラス内の非定 常熱伝導に伴う温度分布の時刻歴を考虑した解析を行い，冷 却過程において生じる内部応力の分布, さらにはレンズ形状 に及ぼす成形パラメータの影響について考察を行った。

\section{2. 理 論}

$2 \cdot 1$ 線形粘弾性体の構成方程式 本研究では, ガラス が線形熱粘弾性体であるものと仮定して議論する ${ }^{(1)}$. 線形熱 粘弾性体においては, 応力の時刻歴 $\sigma(t)$ と, それに対するひ ずみ応答 $\varepsilon(t)$ との間に重ね合わせの原理が成立する.すなわ ち, 両者の関係を, 次式のような Duhamel の畳込み積分に より記述することができる(2).

$$
\varepsilon(t)=\int_{0}^{t} J(t-\tau) \frac{d \sigma(\tau)}{d \tau} d \tau+\sigma(0) J(t)
$$

ここで, $J(t)$ は $t=0$ で単位ステップ状の応力を作用させた 場合のひずみの時間変化であり, クリープ関数と呼ばれる.

同様に，ひずみ履歴 $\varepsilon(t)$ に対応する応力の応答 $\sigma(t)$ は以 下のように記述される.

$$
\sigma(t)=\int_{0}^{t} k(t-\tau) \frac{d \varepsilon(\tau)}{d \tau} d \tau+\varepsilon(0) k(t)
$$

ここで, $k(t)$ は $t=0$ で単位ステップ状のひずみを作用させ た場合の応力の時間変化であり, 緩和弾性係数と呼ばれる

時刻 $t=0$ において, 式 (1) と式 (2) を Laplace 変換し整 理すると，以下の関係が成立する。

$$
\bar{k}(s)=\frac{1}{s^{2} \bar{J}(s)}
$$

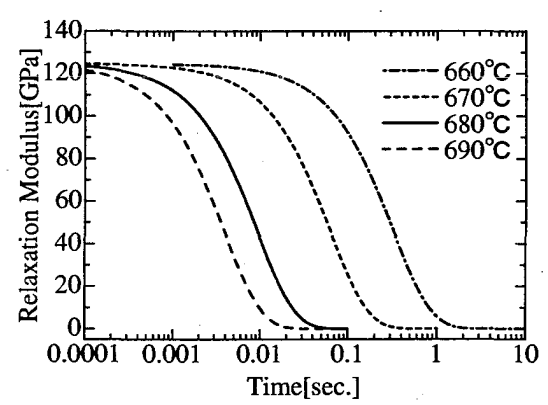

Fig.1 Relaxation modulus $k(t)$ of TaF-3.

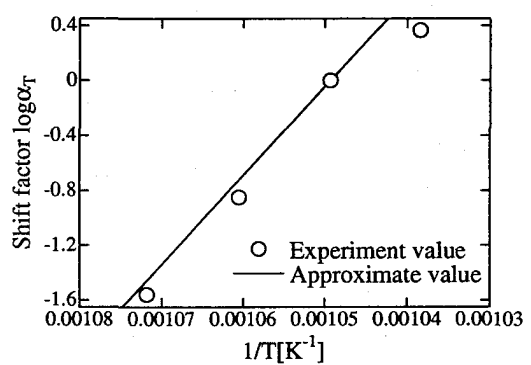

Fig.2 Shift factor of TaF-3 estimated by creep test.

なお $s$ は Laplace 変換パラメータ, “平”を付した緒量は各物 理量の Laplace 変形を表す. 式 (3) の関係式より, 実験的に 求められたクリープ関数 $J(t)$ より, 緩和弾性係数 $k(t)$ を算 出することができる。

$2 \cdot 2$ 時間-温度換算則 熱粘弾性材料は, 構成方程式 が時間と温度の両者に依存する。ここで, 楥和弾性率と温度 $T$ および時間 $t$ の間には時間-温度換算則が成立し, 次式の ように一般化できることが実験的に検証されている。

$$
k\left(\log t, T_{0}\right)=k\left(\log t-\log \alpha_{T_{0}}(T), T\right)
$$

ここで $\alpha_{T_{0}}(T)$ はシフトファクターと呼ばれ，基準温度 $T_{0} に$ 対する温度 $T$ の関数である. 上式は基準温度における緩和 弾性係数とシフトファクターにより任意の温度における緩和 弾性係数が得られることを示している.

\section{3. 数值シミュレーション}

$3 \cdot 1$ 熱粘弾性特性の同定 本研究では，ガラス材の圧 縮クリープ試験を実施した結果より，緩和弾性係数の同定を 実施した．測定されたクリープ関数に線形多項式近似を行っ た後, Laplace 変換し $\bar{J}(s)$ を求め, これを式 (3) に代入し, さらに数值 Laplace 逆変換を行うことにより実時間における

〔№.06-9] 日本機械学会第 19 回計算力学講演会講演論文集〔2006-11.3 5 - 名古屋市 


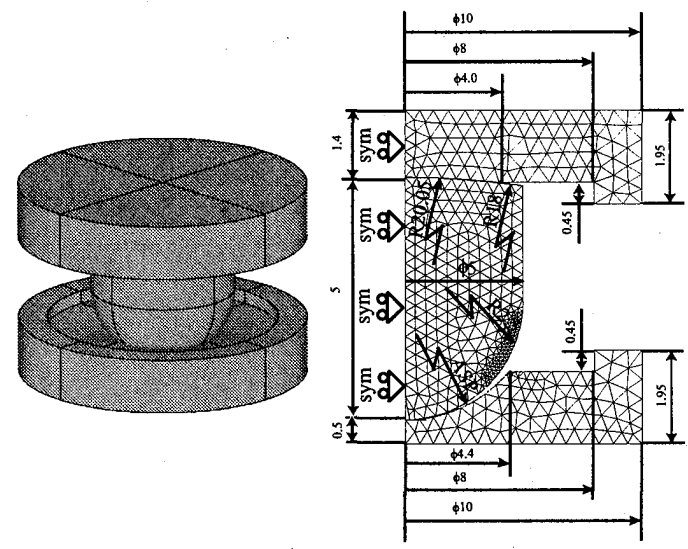

Fig.3 FEM model (aspherical lens).

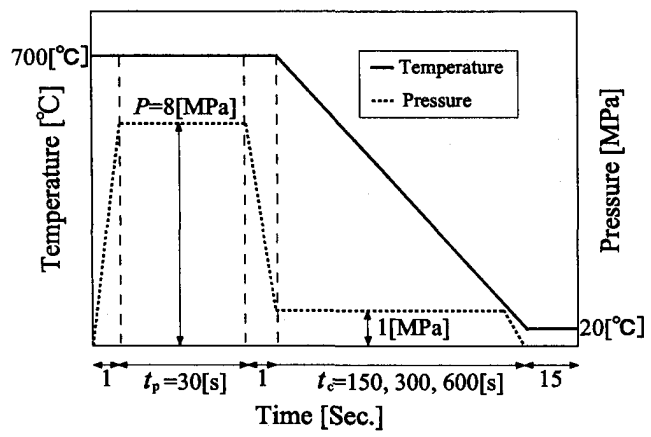

Fig.4 Pressure and temperature condition in forming process.

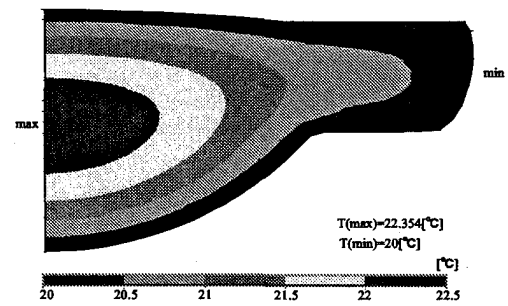

Fig.5 Temperature distribution $\left(\mathrm{t}=332[\mathrm{~s}], t_{c}=300[\mathrm{~s}]\right)$.

緩和弾性係数を算出した. Fig.1に TaF-3 材の緩和弾性係数 を示す。 また，シフトファクターは，Fig.2 に示されるよう に, 硝材のガラス転移温度 $\left(680^{\circ} \mathrm{C}\right)$ における楥和弾性率を 基準として算出したのち, 得られたシフトファクターの離散 データを次式(3)を用いて近似した。

$$
\ln \alpha_{T_{0}}(T)=\frac{\Delta H}{R}\left(\frac{1}{T_{0}}-\frac{1}{T}\right)
$$

ここで, $R$ は気体定数, $T_{0}$ は基準温度， $\Delta H$ は粘性流動の 活性化エネルギーである．Fig.2より，活性化エネルギーは， $\Delta H=539[\mathrm{~kJ} / \mathrm{mol}]$ となった。 さらに, FEM 解析に用いるた めにマスターカーブを次式でに示す Maxwell モデルにより 近似を行った。

$$
k(t)=\sum_{i=1}^{N} k_{i} \exp \left(\frac{-t}{\lambda_{i}}\right)+k_{\infty}
$$

ここで，式 (6) 中の $N$ は 5 とし，未知数である $k_{i}$ および $\lambda_{i}$ を探索により決定した。最終的に同定された Maxwell モデ ルにおける諸定数は以下のとおりである.

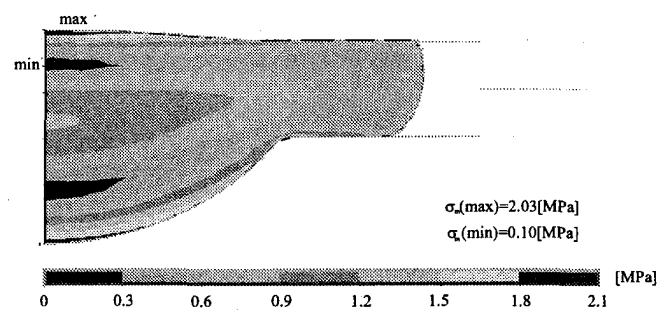

Fig.6 Residual stress (von Mises) $\left(t_{c}=300[\mathrm{~s}]\right)$.

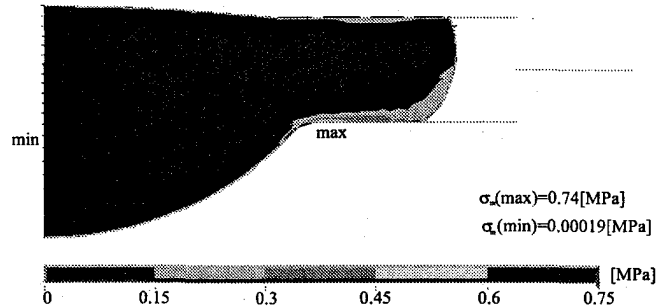

Fig.7 Residual stress (von Mises) $\left(t_{c}=300[\mathrm{~s}]\right.$, uniformly temperature distribution).

$$
\begin{aligned}
& k_{1}=k_{2}=k_{3}=k_{4}=30.88[\mathrm{GPa}], k_{5}=1.248[\mathrm{GPa}] \\
& k_{\infty}=1.97[\mathrm{MPa}] \\
& \lambda_{1}=7.0[\mathrm{~ms}], \lambda_{2}=9.0[\mathrm{~ms}], \lambda_{3}=10.0[\mathrm{~ms}] \\
& \lambda_{4}=11.0[\mathrm{~ms}], \lambda_{5}=30.0[\mathrm{~ms}]
\end{aligned}
$$

3.2 非球面レンズのプレス成形解析 本研究では Fig.3 で示されるような非球面レンズの成形シミュレーションの 結果について示す．解析には汎用有限要素法コード ANSYS ver.9.0を用いた. 解析モデルには二次元軸対称モデルを用 い,三角形 2 次要素を用いてガラス材を 541 要素，金型部分 を 323 要素にて分割した。温度条件と圧力条件を Fig.4 に示 す.

本解析では，冷却過程における伝熱解析を実施すること によりレンズ内の温度分布を考慮した。ただし，温度条件 は，金型およびガラス材外周部に Fig.4 に示される温度条件 を与え伝熱解析を実施し，その温度デー夕を構造解析に用い ることにより実施した，本解析では，温度分布を考虑して冷 却時間を $150[\mathrm{~s}], 300[\mathrm{~s}], 600[\mathrm{~s}]$ と変化させた場合，冷却時間を $300[\mathrm{~s}]$ とし温度分布考慮していない場合について解析を行い, レンズ内部の温度分布がレンズ成形に与える影響について考 察を行った.

Fig.5 に冷却過程終了後の温度の分布図を示す。グラフよ り，レンズの中心と外周に約 $2.4^{\circ} \mathrm{C}$ の温度差が生じているこ とがわかる。.また，レンズ内部の温度分布を考虑しない場合 の解析，温度分布を考慮した場合の解析の解析結果を Fig.6, Fig.7 に示した.これより，冷却過程においてレンズ内部に 発生する温度分布が残留応力に影響を与えることが確かめら れた。 さらには, レンズ内部の温度分布が成形後のレンズ形 状に影響を与えることを確認した。

\section{文献}

（1）例えば，クリュチニコフ他，千野英春訳，ガラスの科学，科学普及新書， (1972), 東京図書

（2）荒井政大，中村淳之介，辰己正和，伊藤寛明，松倉利顥，杉本公一，温度場 の不均一性を考慮したガラスレンズのモールドプレス解析，計算数理工 学論文集，第 5 巻, 2 号, (2005), pp.177-182.

(3) Narayanaswamy, O. S., A Model of Structural Relaxation in Glass, Journal of the American Ceramic Society, Vol.54, No.10, (1971), pp.491-498. 